\title{
Aktif Yurttaşlık İle Dindarlık Durumu Arasındaki İlişkinin Sosyolojik Açıdan İncelenmesi
}

\author{
Doç. Dr. Ensar Çetin ${ }^{1 *}$ \\ Doç. Dr. Kemal Dil ${ }^{2}$ \\ Doktor Öğr. Üyesi Hakan Arslan ${ }^{3}$ \\ Prof. Dr. Sedat Yazıcı ${ }^{4}$
}

Gelis tarihi: 26.08.2019

Kabul tarihi: 10.09.2019

\section{Atıf bilgisi:}

IBAD Sosyal Bilimler Dergisi

Sayı: Özel Sayı Sayfa: 172-184

Yıl: 2019

This article was checked by iThenticate Similarity Index $18 \%$.

\section{${ }^{1}$ Nevșehir Hacı Bektaș Veli Üniversitesi, Türkiye, ensarcetin@yahoo.com, ORCID ID 0000-0002-5668-4988}

2 Çankırı Karatekin Üniversitesi, Türkiye, kemaldil@yahoo.com.

ORCID ID 0000-0003-0106-8712

${ }^{3}$ Ușak Üniveritesi, Türkiye, hakancbu@gmail.com

ORCID ID 0000-0002-9677-6035

${ }^{4}$ Bartın Üniversitesi, Türkiye,

syazici@,bartin.edu.tr.

ORCID ID 0000-0002-7393-0722

\footnotetext{
* Sorumlu yazar
}

\section{öz}

Dindar, dine mensup olma, dini benimseme anlamındadır. Bu açıdan dinin gereğini kabul eden ve bir dine mensup olan herkes bu açıdan dindar sayılabilir. Ancak gündelik hayatta "dindar insan" dendiğinde genellikle sadece bu kadarı kastedilmez veya anlaşılmaz, göreceli olarak dine daha bağlı insan akla gelir. Bir insanın dindarlık durumu dendiğinde de o insanın mensubu olduğu dinin esaslarını içselleştirmesi ve ibadetlerini yerine getirmede gösterdiği bağlllık derecesi anlaşılır. İnsanların gündelik hayat pratiklerinin oluşmasında zihniyet dünyasının, zihniyet dünyasının oluşmasında da inançlar belirleyici rol oynar. Toplumsal bilinç, kolektif ahlaki bilinç ve sosyal bilincin oluşmasında dinin rolünü inceleyen Emile Durkheim, dünya ve insan üzerine görüşler içermeyen herhangi bir dinin olmadığını belirtmiştir. Ona göre, hem felsefenin hem bilimin hem de tüm sosyal kurumların kaynağı dindir. Dinlerin bu özelliğinin soncu olarak insanların inançları ile gündelik hayatta ortaya koyduğu davranış pratikleri arasında direkt veya dolaylı bir ilişki olduğu söylenebilir. Gündelik hayat pratiklerinin önemli bir bölümünü yurttaşlık ilişkileri oluşturur. İnsanların yurttaşlık ilişkilerini sürdürürken ortaya koyduğu gündelik hayat pratikleri ile zihniyet yapılarından dolayısıyla da inanç dünyaları ve dindarlık durumlarından bağımsız değildir. Türkiye'de, Cumhuriyet dönemiyle birlikte somutlaşan ve hız kazanan demokratikleşme sürecinde demokratik karar verme mekanizmalarının çeșitlenmesi, farklılaşması ve karmașıklaşması yurttaşlık katılımını her zamankinden daha fazla önemli hale gelmiştir. Günümüzde etkin ve katılımcı yurttaşlığın önemli olduğu hemen hemen her demokratik kesim sıkça dile getirmektedir. "Yurttaşlık" kavramı hem etimolojik, hem de kavramsal olarak mekâna ve gruba göndermede bulunan bir sözcüktür. Günümüzde yurttaşlığın mekânsal boyutuyla genișlemesi ve katılımcılık boyutuyla farklılașması yurttașlık nitelikleri açısından beklentileri yükseltmiştir. Modern dünyada yurttaşlık ilişkilerindeki bu çeșitlenme "aktif yurttaşlık kavramını ortaya çıkarmıștır. Bu çalışmada, demokratik ve katılımcı yurttaşlı̆g 1 da içine alan aktif yurttaşlık ile dindarlık durumu arasındaki ilişki; aktif yurttaşlığın bilgi, beceri, değer ve katılımcılık boyutları ile dindarlığın inanç, duygu, davranış ve bilgi, boyutları açısından ele alınmıştır. Bu çalışmanın genel amacı yetişkin bireylerin aktif yurttaşlık nitelik ve davranıșları ile dindarlık düzeyli arasındaki ilișkiyi araştırmaktır. Bu kapsamda, katılımcıların yurttaşlık ilgileri, yurttaşlık katılım düzeyleri, karar verme süreçleri, bilgi kaynakları, yurttaşlıkla ilgili hak ve sorumluluk farkındalıkları, yurttaşlık öz-yeterlilikleri ile etkin yurttaşlık katılımcılığının önündeki sosyo-kültürel engelleri dindarlık durumu değişkeni açısından araştırılmıştır. Çalışmada, nicel veri toplama tekniği kullanılmıştır. Araştırmada, nicel veri toplama aracı olarak enlemesine tarama deseni kapsamında anket tekniği kullanılmıştır.

Anahtar Kelimeler: Yurttaşlık/ vatandaşlık, aktif yurttaşlık, dindarlık, din algıs1, demokratik katılım 


\author{
Assoc. Prof. Dr. Ensar Çetin ${ }^{1} *$ \\ Assoc. Prof. Dr. Kemal Dil ${ }^{2}$ \\ Assist. Prof. Dr. Hakan Arslan ${ }^{3}$ \\ Prof. Dr. Sedat Yazıci ${ }^{4}$
}

First received: 26.08 .2019

Accepted: 10.09.2019

\section{Citation:}

IBAD Journal of Social Sciences

Issue: Special Issue Pages: 172-184

Year: 2019

This article was checked by iThenticate. Similarity Index $18 \%$.

\footnotetext{
${ }^{1}$ Nevşehir Hacı Bektaş Veli Üniversitesi, Türkiye, ensarcetin@yahoo.com, ORCID ID 0000-0002-5668-4988 2 Çankırı Karatekin Üniversitesi, Türkiye, kemaldil@yahoo.com.

ORCID ID 0000-0003-0106-8712

${ }^{3}$ Uşak Üniveritesi, Türkiye,

hakancbu@gmail.com

ORCID ID 0000-0002-9677-6035

${ }^{4}$ Bartın Üniversitesi, Türkiye, syazici@bartin.edu.tr.

ORCID ID 0000-0002-7393-0722

* Corresponding Author
}

\begin{abstract}
Religious means being affiliated to and connected with a religion and adopting that particular religion. In this respect, anyone who accept the requirements of religion and who is affiliated to a specific religion can be considered as a religious person. However, when we speak of a "religious person" in daily life, what is meant or understood is usually not this, but relatively, a person more devoted to a religion. And, when we speak of the religious status of a person, how much that person internalizes the tenets of the religion $\mathrm{s} / \mathrm{he}$ is affiliated to and the level of his/her devotion with respect to fulfilling the religious deeds. Mindset plays a determining role in the formation of daily life practices of people, whereas beliefs play a determining role in the formation of the mindset. Upon analyzing the role of religion in the formation of social consciousness, collective moral conscious and social awareness, Emile Durkheim stated that there is no religion which does not involve judgments on the world and humans. In her opinion, religion is the origin of not only philosophy and science, but also all social institutions. As a consequence of such characteristic of religion, it would not be wrong to say that there is a direct or indirect relationship between the beliefs of people and their behavioral practices in their daily lives. Citizenship relations constitute an important part of daily life practices. Daily life practices displayed by people while maintaining their citizenship relations are not independent from their mindsets, therefore, their world of belief and religiousness status. In Turkey, diversification, differentiation and complexification of the democratic decision-making mechanisms in the process of democratization, which took a more concrete form and gained momentum with the Republican period, has made citizenship participation much more important than ever. Today, almost every democratic segment frequently expresses how significant an effective and participatory citizenship is. The concept of "citizenship" is a word that refers to the space and group, both etymologically and conceptually. Expansion of citizenship in terms of space and differentiation of the same in terms of participation has now raised expectations with regards to citizenship qualifications. Such diversification of citizenship relations in the modern world created the concept of "active citizenship". The relationship between the "active citizenship", which involves democratic and participatory citizenship, and the "religiousness status" is addressed in this study from the point of knowledge, skills, values and participation aspects of active citizenship and the point of belief, emotions, behaviors and knowledge aspects of religiousness. The general purpose of this study is to research the relationship between the active citizenship qualifications and behaviors of adult individuals and their level of religiousness. In this context, citizenship interests, citizenship participation levels, decision-making processes, information resources, awareness of citizenship rights and responsibilities, citizenship self-sufficiencies, and socio-cultural obstacles before effective citizenship participation have been researched with regards to religiousness status variable. Quantitative data collection method is used in the study. The questionnaire technique within the framework of cross-sectional scanning pattern has been used as a quantitative data collection tool for the research.
\end{abstract}

Keywords: Citizenship / citizenship, active citizenship, religiousness, religious perception, democratic participation. 


\section{GİRIŞ}

\section{Çalışmanın Amaç ve Kapsamı}

$\mathrm{Bu}$ araştırmada insanların gündelik hayat pratiklerinin çok önemli bir boyutunu oluşturan aktif yurttaşlık ile zihniyetin oluşmasında önemli bir yeri olan dindarlık durumu arasındaki ilişkiyi ortaya koymak amaçlanmaktadır. İnsanların dindarlık durumları ile aktif yurttaşlık düzeyleri arasındaki ilişkinin ortaya konulması dini sosyalleşme açısından oldukça önemlidir. Dinler, mensuplarının karşılaştıkları sıkıntılara tahammül gücünü artırmaktadır. Ancak dinlerin bu fonksiyonu mensuplarını hak arama ve karar alma mekanizmalarına katılma noktasında ters ișlev de yerine getirebilmektedir. Örneğin, dindar bir bireyin haksızlığa uğradığında hakkını yasal yollarla aramak yerine konuyu İlahi adalete havale etmesi söz konusu olabilmektedir. Karar alma mekanizmalarına katılmaya istekli veya isteksiz olmak konusunda da insanların dindarlık durumları etkili olabilmektedir.

Bu amaçlar doğrultusunda, çalışmanın hedeflerini daha somut biçimde şöyle ifade edebiliriz:

Hedef 1 Yetişkin bireylerin dindarlık durumları ile yurttaşlık algı ve farkındalıkları arasındaki ilişkiyi tespit etmek.

Hedef 2Yetişkin bireylerin dindarlık durumlan ile yurttaşlık davranışları ve katılım düzeyleri arasındaki ilişkiyi tespit etmek.

$\mathrm{Bu}$ çalışmanın konusu en genel şekliyle "Gündelik Hayat Sosyolojisi” açısından Türkiye'de aktif yurttaşlık profil, özellik ve süreçlerini tespit etmek olarak düşünülebilir. Bu bağlamda Türkiye'nin belirlenmiş araştırma alanlarında yurttaşlık, aktif yurttaşlık, katılımcı yurttaşlık ile dindarlık arasında ilişki olup olmadığı araştırılmaktadır.

Dindarlık ve aktif yurttaşlık konuları ulusal ve uluslararası literatürde yaygın bir şekilde çalışılmaktadır. Günümüzde dünyada dindarlık ve yurttaşlıkla ilgili üniversite bünyelerinde çok sayıda çalışmanın yapıldığı görülmektedir. Ancak dindarlık ile aktif yurttaşlık arasındaki ilişkiye odaklanan çalışma sayısı yok denebilecek kadar azdır. Dindarlık ile aktif yurttaşlık arasındaki ilişkiyi ortaya koymaya çalıştığımız bu araştırmanın bu alana katkı yapacağı düşünülmektedir.

Çalışmanın konusunu daha açık bir şekilde ifade etmek açısından araştırmanın ana problem cümlesi ile alt problem cümlelerine yer vermekte yarar vardır.

Problem Cümlesi: Yetişkin bireylerin dindarlık durumları ile aktif yurttaşlık düzeyleri arasında nasıl bir ilişki vardır?

\section{Alt problem cümleleri:}

Yetişkin bireylerin dindarlık durumları ile aktif yurttaşlık farkındalık boyutu düzeyleri arasında nasıl bir ilişki vardır?

Yetişkin bireylerin dindarlık durumları ile aktif yurttaşılı katılım boyutu arasında nasıl bir ilişki vardır?

Yetişkin bireylerin dindarlık durumları ile aktif yurttaşlık bilgi boyutu arasında nasıl bir ilişki vardır?

Yetişkin bireylerin dindarlık durumları ile aktif yurttaşlık beceri boyutu arasında nasıı bir ilişki vardır?

\section{Çalışmanın Özgün Değeri}

Demokratik yönetimlerde yurttaşlık niteliklerinin ve katılımının öneminin farkına varan hemen hemen her kesimden yurttaşların sivil, siyasi ve toplumsal yaşama, karar verme mekanizmalarına, yurttaşların kendilerini temsil eden veya kararlarıyla etkileyebilecek örgütlere katılmaları konusunda teşvik edici mesajlar yükselmektedir. Ulusal hükümetler, $\mathrm{AB}$, yerel yönetimler ve ulusal ve uluslararası sivil toplum örgütleri bu konuda birçok somut adım atarak araştırma, geliştirme ve eğitimsel faaliyette bulunmaktadırlar. Ancak, aktif ve katılımcı yurttaşlık açısından gelişmiş demokratik ülkelerin bile arzulanan hedeflerden uzakta olduğu bilinen bir gerçektir (Geddes, 2000; Herbert, Cheshire ve Higgins, 2004; Morell ve Bock, 2008). Bu eğilimin ve davranışın altında yatan nedenleri, yapıları, motivleri veya motivasyon eksikliklerini, ilişkileri, sosyal, kültürel, siyasal ve ekonomik engelleri anlamaya ve açıklamaya yönelik çalışmalara ihtiyaç vardır. 
Türkiye'de aktif ve katılımcı yurttaşlıkla ilgili "Aktif Yurttaşlık Ölçme Aracının Geliştirilmesi Üzerine Bir Çalışma" isimli makale (Yazıcı, Arslan vd., 2017, s. 251- 272). "Aktif yurttaşlık öz-yeterlik ölçeği Bir geçerlik ve güvenirlik çalışması- AYÖYÖ" isimli makale (Arslan, Yazıcı vd., 2017) ve "Dindarlık Durumu ile Aktif Yurttaşlık Arasındaki İlişkinin Sosyolojik Açıdan İncelenmesi" sözlü bildiri sunumu (Çetin, Yazıcı vd., 2017, s. 290) gibi çalışmalar mevcuttur. Bu çalışmalar genel olarak yurttaşlığı eleştirel düşünme, kırsal yaşam, kent yaşamı ve aktif yurttaşlık bağlamlarında ele almaktadır. Yapılan literatür çalışmasında aktif yurttaşlık ile dindarlık arasında nasıl bir ilişki olduğunu ele alan bir çalışmaya rastlayamadık. Bu nedenle araştırmamızı aktif yurttaşlık ile dindarlık arasındaki ilişkiyi ele alması bakımından özgün bir değere sahip olduğu kanaatindeyiz. Araştırmamızın bu alanda ilk çalışma olduğunu söylemek aşırı iddialı olacaktır, ancak çalışmamızın bu konuda ilklerden olduğu söylenebilir.

\section{Yöntem ve Materyal}

Bu çalışmada, tarama modeli kapsamında betimleyici araştırma yöntemi kullanılmıştır. Betimleyici yöntem belli bir durumu tespit etmeye yönelik araştırma modelidir. Betimleyici araştırma kapsamında genel olarak, davranışlar, tutumlar, inançlar, görüşler, değerler, ilkeler, özellikler, beklentiler, bilgiler ve sınıflandırmalar incelenir (Neuman, 2007). Çalışmada, nicel veri toplama tekniklerinin yer aldığı araştırma ve çözümleme deseni kullanılmıştır.

\section{Veri Toplama Araçları}

Dindarlık Durumu Ölçeği (DDÖ): Ancak Sosyolojik acıdan dinin toplumdaki etkisi göz önünde bulundurularak yapılan dindarlık tanımı yapılacak olursa "dindar" özetle bir kutsala inanan, inançları gereği işler yapan ve dinî bir grubun üyesi olan kimsedir. Dindar ( mütedeyyin) ise mensubu olduğu dinin inanç, ilke, pratik ve sembollerini içselleştirip bunları tutum ve davranışlarında sergileyen kişidir (Arslantürk, 2004, s. 239; Yıldız, 2001, s. 23). Türkiye'de ve Dünyada çok sayıda dindarlık ölçeği mevcuttur. Ancak din alanı kısmen özel bir alan olduğu için farklı din mensuplarının dindarlık durumları ölçmek için daha özel ölçeklerin geliştirilmesi zorunludur. Biz araştırma örneklemimizden daha nesnel veriler toplayabilmek için İslam dinine inananların dindarlık durumları ölçmeye yönelik bir ölçek geliştirdik.

$\mathrm{Bu}$ çalışmada kullanılan dindarlık ölçeği 19 sorulu beşli likert tipi ölçekten oluşmaktadır. Ölçeğin oluşturulması aşamasında kitabi dindarlık ve halk dindarlığı olmak üzere iki alt boyutta sorular oluşturulmuştur. Bu ölçeğin özellikle halk dindarlığı alt boyutunun hazırlanmasında Mustafa Arslan'ın geliştirdiği ve Türkiye'de dindarlık çalışan birçok araştırmacı tarafindan da kullanılan "Popüler Dindarlık Ölçeğiı”nden (PDO) yararlanılmıştır (Arslan, 2003). Ölçek (KMO and Bartlett's Test: ,885, Cronbach's Alpha iç tutarlılık katsayısı 813'tür.

Aktif Yurttaşılı Ölçme Aracı (AYÖA): AYÖA bir birleşik gösterge (composite indicator) ölçme aracıdır. Birleşik gösterge veya indeks, birçok gösterge kümesinin matematiksel toplamından oluşur. Bir niteliği veya değişkeni birleşik gösterge yoluyla ölçmenin birçok olumlu yönü vardır (CIRG, 2016): Birleşik göstergeler resmin bütünü gösterirler. Karmaşık veya çok boyutlu sorunları özetledikleri için karar vericilere kolaylık sağlarlar (Arslan, Yazıcı vd. 2016).

AYÖA her dört boyuttaki göstergelere eşit ağırlık verir. Bu boyutlar içinde yer alan alt boyutlar da kendi içinde eşit ağırlıktadır. Ağırlık seçimi her bir boyutun aktif yurttaşlık için aynı derecede önemli görülmesine göre belirlenmiştir.

Nicel veri toplama aracı: Araştırmacılar tarafindan geliştirilecek nicel veri toplama anketinde çeşitli demografik soruların yanı sıra katılımcıların dindarlık ve yurttaşlık kavramından ne anladıkları; dindarlık durumu ve din algısı; yurttaşlıkla ilgili temel sorunlar; sivil, siyasal ve sosyal katılımları; yurttaşlık hak ve sorumlulukları konusundaki farkındalıkları; bilgi kaynakları ve ağları; yerel liderlerin rolleri, kendilerini veya başka insanları etkileyebilecek yerel, ulusal veya uluslararası düzeydeki olaylar hakkındaki farkındalıkları hakkında yapılandırılmış sorular yer almıştır.

Hazırlanan veri toplama aracında yer alan soruların katılımcılara sorulmasında etik açıdan herhangi sorun olup olmadığı ile ilgili etik kurul raporu alınmış ve veriler toplanma aşamasına geçilmiştir. Daha sonra elde edilen verilerin çözümlemesi SPSS 22 programı aracılığıyla yapılacak yüzde, frekans, ortalama değerleri verilerek Chi-kare testi, korelasyon ve regresyon analizi gibi testler uygulanmıştır. 
Araştırma dört ilde (Ankara, Çankırı, Çorum, İstanbul) gerçekleştirilmiştir. Araştırma evrenimiz Türkiye'de yaşayan 18 ve üstü yaş grubundaki bireyler oluşturmaktadır. Farklı sosyo- ekonomik ve sosyo- kültürel özellikleri olan bireylere ulaşmayı kolaylaştıracağı varsayımından hareketle alan araştırması için küçük, orta, büyük şehir ve metropol seçilmiştir.

Araştırmaya yaşadığımız şehir olan Çankırı merkez ilçesinde yapılan pilot çalışma ile başlanmıştır. Daha sonra Çankırı ilinin de içinde bulunduğu dört ilde devam edilmiş ana çalışmalar bu illerde gerçekleştirilmiştir. Bu illerin seçilmesinde görelide sosyo- ekonomik ve sosyo- kültürel açıdan farkl1lık araz etmesi etkili olmuştur. Ayrıca bu şehirler nüfus büyüklüğü bakımından da küçükten büyüğe sıralanmaktadır. $\mathrm{Bu}$ da bu illerin seçilmesindeki diğer bir etken olmuştur. Bu şekilde araştırma evreni olarak seçtiğimiz bu şehirlerde yaşayan 18 ve üstü yaş grubunda bulunan kadın ve erkek bireylere toplamda 272 katılımcıya anket uygulanmıştır. Katılımeı sayısı ölçek soru sayılarının yaklaşık olarak on katı olarak belirlenmiştir. Daha sonra yapılan kontrolde özensiz cevaplandığını düşündüğümüz veya eksik cevaplanmış 21 anket değerlendirme dışı bırakılarak kalan 251 katılımcının cevapladığı anketler üzerinden analizler yapılmıştır.

\section{Literatür Özeti}

Dindarlık (Ar. tedeyyün, ing. religiosity, religiousness, piety), izafi bir kavramdır ve din ile dinî davranış1 tanımlamalarından bağımsız olarak ele alınamaz. Hatta din kavramı ile dinî davranıșın tanımında ortaya çıkan çeşitlilik ve bunlardan kaynaklanan belirsizlikler çoğu kez dindarlık kavramı için de geçerlidir. Bu tanımlar, sadece dinin özüne ve dini algılayana göre değil, dini yorumlayan bakış açısına göre de farklılık gösterebilir(Kurt, 2009, s. 2). Ancak Sosyolojik acıdan dinin toplumdaki etkisi göz önünde bulundurularak yapılan dindarlık tanımı yapılacak olursa "dindarlık" özetle bir kutsala inanan, inançları gereği işler yapan ve dinî bir grubun üyesi olan kimsedir. Dindar(mütedeyyin) ise mensubu olduğu dinin inanç, ilke, pratik ve sembollerini içselleştirip bunları tutum ve davranışlarında sergileyen kişidir (Arslantürk, 2004, s. 239; Y1ldı, 2001, s. 23).

Dindarlık literatüründe, dindarlığın uygulama alanı şu boyutlarda ortaya çıkar: Kitabi Dindarlık Alt Boyutu Halk Dindarlığı Alt Boyutu

Aktif yurttaşlık çeşitli düzeydeki katılımcılı̆̆ın yanı sıra, bilgi, beceri, değer ve farkındalık boyutlarını içermesi bakımından katılımcı yurttaşlık kavramından daha geniştir. Bu çalışmada esas aldığımız aktif yurttaşlık kavramı bu bağlamda, yani geniş anlamdaki kullanımı ifade etmektedir. Aktif yurttaşlık, siyasi katılımdan, toplumsal sorumluluğa, çevre duyarlılığına çeşitli etkinlikleri kapsar. Avrupa Komisyonu'na bağl "General Joint Research Centre Institute for the Protection and Security of the Citizen" tarafindan çeşitli aralıklarla sürdürülen Avrupa ülkeleri yurttaşlık araştırmalarında aktif yurttaşlık dört boyut üzerinden ölçülmektedir: Siyasi hayata, sivil topluma, topluluk hayatına katılma ve etkili yurttaşlık için gerekli olan değerler (Hoskins vd, 2006).

\section{Yurttaşlık literatüründe, aktif yurttaşlı̆ğın uygulama alanı şu boyutlarda ortaya çıkmaktadır:}

Bilgi boyutu (Yurttaşlık bilinci, hak ve sorumluluk bilinci ve güncel olayları takip etme)

Beceri Boyutu (Soruşturma, hakkını arama)

Değer Boyutu (Toplumsal sorunlara duyarlılık)

Katılımcılık Boyutu (oy verme, siyasi katılım, parti çalışmalarına aktif katılım) (Arslan, Yazıcı vd., 2016).

Aktif yurttaşlık kavramı demokratik ve katılımcı yurttaşlığı da içine alan bir kavramdır ve tüm demokratik yurttaşlık eğitiminin amacı böyle bir yurttaşlık tipi oluşturmaktır. Çünkü aktif yurttaş temel demokratik değerlere inanır ve onlarla yaşamaya çalışır; kendisinin, ailesinin ve toplumunun iyiliği için sorumluluk kabul eder; içinde yaşadığı yerel topluma, ulusa ve dünyaya ilişkin olaylar ile temel belgeler, sivil kurumlar ve siyasi süreçler hakkında bilgi sahibidir; yerel, ulusal ve küresel düzeyde insanlara etkisi olan olay ve sorunların farkındadır; kamusal ve özel yaşamda etkili karar verme ve problem çözme becerisi kullanır; bilgili düşünceler ve yaratıcı çözümler geliştirmek için farklı kaynaklardan ve görüş açılarından bilgiler araştırır; anlamlı sorular sorar, bilgi ve fikirleri değerlendirebilir ve çözümleyebilir; etkili işbirliği kurma becerisine sahiptir; sivil ve toplumsal yaşama etkili bir şekilde katılır (NCSS, 2001). 
Görüldüğ̈̈ gibi aktif yurttaş, hem belli temel değerlere, bilgiye ve beceriye sahiptir hem de bu kişilik erdemlerini siyasi, ekonomik, kültürel ve çevresel konularda katılımcılık davranışıyla gösterir.

\section{Ölçek Geçerlik ve Güvenirlik Analizleri}

\begin{tabular}{|c|c|c|}
\hline \multicolumn{3}{|c|}{ Aktif Yurttaşlık Boyutu } \\
\hline & & Faktör \\
\hline \multirow{5}{*}{$\begin{array}{l}\text { Bilgi Boyutu } \\
\text { Öz değeri: } 6.298 \\
\text { Var. \% } 27.382\end{array}$} & 1.Siyasete ne kadar ilgi duyuyorsunuz? & .620 \\
\hline & $\begin{array}{l}\text { 2.Çevrenizdeki insanlarla ne siklıkla siyaset } \\
\text { konuşursunuz? }\end{array}$ & .644 \\
\hline & $\begin{array}{l}\text { 3.Çevrenizdeki insanlarla yaşadığınız } \quad \text { yerdeki } \\
\text { (köy/mahalle/semt) }\end{array}$ & .659 \\
\hline & $\begin{array}{l}\text { 4.Çevrenizdeki insanlarla Türkiye'deki güncel olayları ne } \\
\text { sıklıkla konuşursunuz? }\end{array}$ & .682 \\
\hline & $\begin{array}{l}\begin{array}{l}\text { 5.Çevrenizdeki insanlarla yaşadığınız yerdeki } \\
\text { (köy/mahalle/semt) }\end{array} \text { olayları ne sıklıkla konuşursunuz? } \\
\end{array}$ & .631 \\
\hline \multirow[t]{3}{*}{$\begin{array}{l}\text { Değer Boyutu } \\
\text { Öz değeri:3.300 } \\
\text { Var. \% } 14.350\end{array}$} & $\begin{array}{l}\text { 6.Sizce, vatandaşların bir haksızlı̆̆ı duyurmak ve } \\
\text { tepkilerini göstermek için gösteri yapmaları ne kadar } \\
\text { önemlidir? }\end{array}$ & .584 \\
\hline & $\begin{array}{l}\text { 7.Sizce, vatandaşların serbest seçimler yoluyla kendi } \\
\text { temsilcilerini seçebilmesi ne kadar önemlidir? }\end{array}$ & .541 \\
\hline & $\begin{array}{l}\text { 8.Sizce, temel hak ve özgürlüklerin insanları devlet } \\
\text { baskısından koruması ne kadar önemlidir? }\end{array}$ & .585 \\
\hline \multirow{10}{*}{$\begin{array}{l}\text { Beceri Boyutu } \\
\text { Öz değeri:2.076 } \\
\text { Var. \% } 9.025\end{array}$} & 9.Başkalarına yardım etme becerime güveniyorum. & .463 \\
\hline & $\begin{array}{l}\text { 10.Çevremdeki veya bulunduğum toplumdaki sosyal } \\
\text { sorunlara katkı yapabilirim. }\end{array}$ & .497 \\
\hline & $\begin{array}{l}\text { 11.Kendi toplumumu (köyümü/mahallemi) geliştirecek } \\
\text { faaliyetlere rahatllkla katıllabilirim. }\end{array}$ & .603 \\
\hline & $\begin{array}{l}\text { 12.Bir derneğin, vakfin veya başka insanların düzenlediği } \\
\text { faaliyetlere rahatlıkla katılabilirim. }\end{array}$ & .576 \\
\hline & $\begin{array}{l}\text { 13.Çevremdeki veya bulunduğum toplumdaki sorunlarla } \\
\text { ilgilenebilirim. }\end{array}$ & .554 \\
\hline & 14.Bir haksızlığa uğradığımda hakkımı arayabilirim. & .607 \\
\hline & $\begin{array}{l}\text { 15.Bir devlet dairesine gittiğimde, derdimi rahatlikla } \\
\text { anlatabilirim. }\end{array}$ & .406 \\
\hline & $\begin{array}{l}\text { 16.Yaşadığım yerin doğal çevresine zarar verildiğinde } \\
\text { buna karşı çıkabilirim. }\end{array}$ & .574 \\
\hline & 18.Haksız gördüğüm bir şeyi protesto edebilirim. & .494 \\
\hline & 19.Ortak bir tepki için insanlarla bir araya gelebilirim. & .437 \\
\hline \multirow{5}{*}{$\begin{array}{l}\text { Katılıme1 Boyutu } \\
\text { Öz değeri:1.754 } \\
\text { Var. \% } 7.627\end{array}$} & 20- Siyasi bir parti ya da eylem grubunda çalışmak & .530 \\
\hline & 21- Başka bir organizasyon ya da dernekte çalışmak & .598 \\
\hline & $\begin{array}{l}\text { 22- Bir kampanya rozeti ya da çıkartması takmak ya da } \\
\text { göstermek }\end{array}$ & .585 \\
\hline & 23- Yasal bir gösteriye katılmak & .559 \\
\hline & 24- Belirli ürünleri boykot etmek & .450 \\
\hline
\end{tabular}




\begin{tabular}{|c|c|c|}
\hline \multicolumn{3}{|c|}{ Dindarlık Durumu Boyutu } \\
\hline Alt Boyutlar & Sorular & Faktör \\
\hline \multirow{12}{*}{$\begin{array}{l}\text { Kitabi Dindarlık } \\
\text { Boyutu } \\
\text { Öz değeri: } 8.901 \\
\text { Var. \% } 46.847\end{array}$} & 1. Allah'ın varlığına inanırım. & .772 \\
\hline & 2. Meleklerin varlığına inanırım & .857 \\
\hline & $\begin{array}{l}\text { 3. Ahiret hayatının (Cennet ve Cehenneme) varlığına } \\
\text { inanırım. }\end{array}$ & .857 \\
\hline & 4. Kur'an-1 Kerim Allah'ın gönderdiği bir kitaptır. & .850 \\
\hline & $\begin{array}{l}\text { 5.Kur'an'da anlatılanlar her çağda insanlara doğruyu } \\
\text { gösterir. }\end{array}$ & .759 \\
\hline & 6.İnançlı bir insanım & .782 \\
\hline & 7. Dua ederim. & .785 \\
\hline & 8. Kur'an-1 Kerim okurum. & .538 \\
\hline & 9. Oruçlarımı düzenli olarak tutarım. & .766 \\
\hline & 10. Namazlarımı düzenli olarak kılarım. & .588 \\
\hline & 11. Genel olarak hayatımı dini inancıma göre düzenlerim. & .717 \\
\hline & $\begin{array}{l}\text { 12. Başıma gelebilecek olayları engellemek için sadaka } \\
\text { veririm. }\end{array}$ & .604 \\
\hline \multirow{7}{*}{$\begin{array}{l}\text { Kitabi Dindarlık } \\
\text { Boyutu } \\
\text { Öz değeri: } 2,305 \\
\text { Var. \% } 12.132\end{array}$} & 13. Cevşen/ muska vb. taşımak kaza ve belalardan korur & .772 \\
\hline & 14. Kur'an okunmuş su insana şifa verir. & .848 \\
\hline & $\begin{array}{l}\text { 15. İnsanların başı derde girdiğinde 'Hızır' veya başka } \\
\text { manevi varlıkların yardımcı olacağına inanırım. }\end{array}$ & .792 \\
\hline & $\begin{array}{l}\text { 16. Ölünün ruhunun huzurlu olmas1 için bazı günlerde } \\
\text { (yedisi, kırk1, vb.) ölünün ruhuna mevlit okutmak gerekir. }\end{array}$ & .788 \\
\hline & 17. Türbede dua edersem dileklerim yerine gelir & .678 \\
\hline & 18. Dualarımın kabulü için türbeleri ziyaret ederim. & .628 \\
\hline & $\begin{array}{l}\text { 19. Manevi gücü olduğuna inandığım bazı insanlardan } \\
\text { manevi yardım alırım }\end{array}$ & .622 \\
\hline
\end{tabular}

Cumulative \% 58,980Cronbach's Alpha.: 923

\section{Bulgular}

Bulguların sunulmasında öncelik demografik değişkenlere verilmiştir. Ardından aktif vatandaşlığın geniş çerçevesi içerisinde yer alan dört boyuta ilişkin elde edilen veriler paylaşılmaktadır. Bu sistematik yaklaşım doğrultusunda aktif vatandaşlığının ilk olarak aktif yurttaşlık "bilgi" (ve ilgi), ardından "değer", "katılım" ve "beceri" boyutlarına ilişkin bulgulara yer verilecektir. Daha sonra ise dindarlık inanç ve ibadet boyutuna ilişkin veriler sunulmaktadır. Son olarak ise Dindarlık İle Aktif Yurttaşlık Arasındaki İlişki ortaya konulmaya çalışılmaktadır.

\section{Demografik Değişkenlere İlişkin Bulgular}

Tablo 1 Cinsiyet

\begin{tabular}{|l|l|l|}
\hline & Sayı $(\mathrm{N})$ & $\%$ \\
\hline Erkek & 95 & 37,8 \\
\hline Kadın & 156 & 62,2 \\
\hline Total & 251 & 100,0 \\
\hline
\end{tabular}

Araştırmaya katılan katılımcı grup incelendiğinde, katılımcı grubunun \% 37.8'ini erkeler \% 62.2'sini kadılar oluşturmaktadır. Bu çalışmada kadınların oranı erkelere göre daha yüksektir. Ancak her ne kadar yaş, cinsiyet, eğitim, ekonomik durum vb. ile aktif yurttaşlık arasında bir ilişki veya bu olgusal durumlar arasında farklılaşmaların olabileceği öngörülse de bu araştırma katılımcıların dindarlık durumları ile aktif yurttaşlık durumları arasındaki ilişkiyi ortaya kayma çabasıyla sınırlıdır. 
Tablo 2 Yaş

\begin{tabular}{|l|l|l|}
\hline & Say1 $(\mathrm{N})$ & $\%$ \\
\hline $16-25$ & 171 & 68,1 \\
\hline $26-35$ & 26 & 10,4 \\
\hline $36-45$ & 25 & 10,0 \\
\hline $46-55$ & 21 & 8,4 \\
\hline $56-65$ & 7 & 2,8 \\
\hline $66+$ & 1 &, 4 \\
\hline Total & 251 & 100,0 \\
\hline
\end{tabular}

Katılımcıların \%68,1'i 16-25 yaş aralığında, \%10.4’ü 26- 35 yaş aralığında, \%10'u 36- 45 yaş aralığında, \%8.4'ü 46- 55 yaş aralında, \% 2.8'i 56- 65 yaş aralığında, \%0.4’ü ise 65 ve üstü yaş grubundaki bireylerden oluşmaktadır. Katılımcıların büyük bir çoğunluğu 16- 45 yaş aralığında yoğunlaşmıştır.

Tablo 3 Medeni durum

\begin{tabular}{|l|l|l|}
\hline & Sayı $(\mathrm{N})$ & $\%$ \\
\hline Evli & 69 & 27,5 \\
\hline Bekâr & 181 & 72,1 \\
\hline Dul & 1 & 4 \\
\hline Total & 251 & 100,0 \\
\hline
\end{tabular}

Katılımcıların \%27,5'i evli, \%72.1' bekar, \% 0.4'ü dul bireyler oluşturmaktadır. Katılımcıların çoğunun bekar olmasında örneklem grubumuza giren katılımcıların çoğunun genç olması ve evlenme yaşının göreceli olarak yükselmeye başlaması etkili olmuş olabilir.

Tablo 4 Mezhep

\begin{tabular}{|l|l|l|}
\hline & Say1 $(\mathrm{N})$ & $\%$ \\
\hline Sünni & 197 & 78,5 \\
\hline Alevi & 16 & 6,4 \\
\hline Diğer & 38 & 15,1 \\
\hline Total & 251 & 100,0 \\
\hline
\end{tabular}

Mezhebiniz nedir sorusuna katılımcıların \% 78.5'i Sünni, \% 6.4'ü Alevi cevabını vermiştir. Katılımcıların \% 15,1 ise mezheple ilgili bu soruyu cevapsız bırakmışır.

Tablo 5 Siyasi eğilim

\begin{tabular}{|l|l|l|}
\hline & Sayı $(\mathrm{N})$ & $\%$ \\
\hline Milliyetçi & 48 & 19,1 \\
\hline Sosyalist & 15 & 6,0 \\
\hline Komünist & 2 & 8 \\
\hline Kemalist & 25 & 10,0 \\
\hline Muhafazakâr & 46 & 18,3 \\
\hline İslamc1 & 33 & 13,1 \\
\hline Milliyetçi- muhafazakâr & 46 & 18,3 \\
\hline Sosyal- demokrat & 15 & 6,0 \\
\hline Liberal & 1 &, 4 \\
\hline Diğgr & 20 & 8,0 \\
\hline Total & 251 & 100,0 \\
\hline
\end{tabular}

Kendinizi hangi siyasi eğilime daha yakın görüyorsunuz, sorusuna katılımcıların \% 19.1'i milliyetçi, \% 6's1 sosyalist, \% 0.8'i komünist, \% 10'u Kemalist, \%18.3'ü muhafazakâr, \% 13.1'i İslamc1, \% 18.3'ü milliyetçi- muhafazakar, \% 6'sı sosyal demokrat, \% 0.4'ü liberal cevabını vermiştir. Katılımcıların \% 8'i ise bu soruyu cevapsız bırakmıştır. 
Tablo 6 Eğitim Durumu

\begin{tabular}{|l|l|l|}
\hline & Sayı $(\mathrm{N})$ & $\%$ \\
\hline Okur- yazar & 4 & 1,6 \\
\hline Illkokul & 10 & 4,0 \\
\hline Ortaokul & 5 & 2,0 \\
\hline Lise & 21 & 8,4 \\
\hline Üniversite & 81 & 32,3 \\
\hline Üniversite öğrencisi & 108 & 43,0 \\
\hline Lisansüstü & 15 & 6,0 \\
\hline Lisansüstü öğrencisi & 7 & 2,8 \\
\hline Total & 251 & 100,0 \\
\hline
\end{tabular}

Katılımcıların \% 4'dü ilkokul, \% 2'si ortaokul, \% 8.4'ü lise, \% 32.3'ü üniversite, \% 6'sı lisansüstü mezunu; \% 43. 3'ü üniversite öğrencisi, \% 2.8'i lisansüstü öğrencisi; \% 1.6'sı okur- yazar kişilerden oluşmaktadır.

\section{Dindarlık Durumu İle Aktif Yurttaşık Arasındaki İlişkinin İncelenmesi}

Tablo 7 Dindarlık İle Aktif Yurttaşıı Arasındaki İlişki (Correlations)

\begin{tabular}{|c|c|c|c|c|c|c|c|c|}
\hline \multicolumn{9}{|l|}{ Correlations $^{\mathrm{c}}$} \\
\hline & & 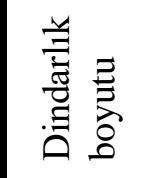 & 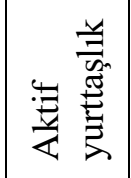 & $\begin{array}{l}\overrightarrow{8} \\
\frac{0}{00} \\
\frac{0}{\infty} \Xi\end{array}$ & 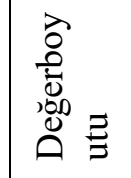 & 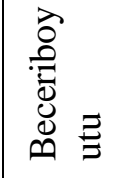 & 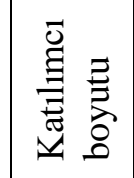 & 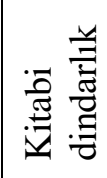 \\
\hline \multirow{2}{*}{$\begin{array}{l}\text { Aktif } \\
\text { Yurttaşlik }\end{array}$} & Pearson Correlation & $-.135^{*}$ & & & & & & \\
\hline & Sig. (2-tailed) & .017 & & & & & & \\
\hline \multirow[t]{2}{*}{ Bilgi boyutu } & Pearson Correlation & -.079 & $.609^{* *}$ & & & & & \\
\hline & Sig. (2-tailed) & .107 & .000 & & & & & \\
\hline \multirow{2}{*}{$\begin{array}{l}\text { Değer } \\
\text { boyutu }\end{array}$} & Pearson Correlation & $-.203^{* *}$ & $.391^{* *}$ & $.146^{*}$ & & & & \\
\hline & Sig. (2-tailed) & .001 & .000 & .010 & & & & \\
\hline \multirow{2}{*}{$\begin{array}{l}\text { Beceri } \\
\text { boyutu }\end{array}$} & Pearson Correlation & .031 & $.835^{* *}$ & $.291^{* * *}$ & $.148^{* *}$ & & & \\
\hline & Sig. (2-tailed) & .311 & .000 & .000 & .010 & & & \\
\hline \multirow{2}{*}{$\begin{array}{l}\text { Katılimc1 } \\
\text { boyutu }\end{array}$} & Pearson Correlation & $-.289^{* * *}$ & $.605^{* *}$ & $.356^{* * *}$ & $.249^{* *}$ & $.182^{* * *}$ & & \\
\hline & Sig. (2-tailed) & .000 & .000 & .000 & .000 & .002 & & \\
\hline \multirow{2}{*}{$\begin{array}{l}\text { Kitabi } \\
\text { dindarlik }\end{array}$} & Pearson Correlation & $.922^{* *}$ & $-.129^{*}$ & -.096 & $-.150^{* *}$ & .022 & $-.262^{* *}$ & \\
\hline & Sig. (2-tailed) & .000 & .020 & .064 & .009 & .364 & .000 & \\
\hline \multirow{2}{*}{$\begin{array}{l}\text { Halk } \\
\text { dindarlığ1 }\end{array}$} & Pearson Correlation & $.848^{* *}$ & $-.107^{*}$ & -.034 & $-.223^{* *}$ & .036 & $-.251^{* *}$ & $.575^{* *}$ \\
\hline & Sig. (2-tailed) & .000 & .045 & .296 & .000 & .286 & .000 & .000 \\
\hline \multicolumn{9}{|c|}{ *. Correlation is significant at the 0.05 level (2-tailed). } \\
\hline \multicolumn{9}{|c|}{ **. Correlation is significant at the 0.01 level (2-tailed). } \\
\hline \multicolumn{9}{|c|}{ c. Listwise $\mathrm{N}=251$} \\
\hline
\end{tabular}

Dindarlık boyutu ve dindarlık alt boyutları ile aktif yurttaşlık boyutu ve aktif yurttaşlık alt boyutları arasında yapılan SPSS 22 korelasyon analizinin sonuçları aşağıdaki şekilde gerçekleşmiştir.

1. Aktif yurttaşlık boyutu ile dindarlık boyutu arasında eksi (-) yönde 0,135 puanlık bir ilişki olduğu görülmektedir.

2. Aktif yurttaşlık boyutu ile kitabi dindarlık alt boyutu arasında eksi (-) yönde 0,129 puanlık bir ilişki olduğu görülmektedir

3. Aktif yurttaşlık boyutu ile hak dindarlığı alt boyutu arasında eksi (-) yönde 0,107 puanlık bir ilişki olduğu görülmektedir. 
4. Aktif yurttaşık boyutu ile aktif yurttaşlık beceri alt boyutu arasında artı $(+)$ yönde 0,835 puanlık bir ilişki olduğu görülmektedir

5. Aktif yurttaşlık boyutu ile aktif yurttaşlık katılımeı alt boyutu arasında artı $(+)$ yönde 0,605 puanlık bir ilişki olduğu görülmektedir.

6. Aktif yurttaşık boyutu ile aktif yurttaşlık değer alt boyutu arasında artı $(+)$ yönde 0,391 puanlık bir ilişki olduğu görülmektedir

7. Aktif yurttaşlık boyutu ile aktif yurttaşık bilgi alt boyutu arasında artı (+) yönde 0,609 puanlık bir ilişki olduğu görülmektedir

8. Dindarlık boyutu ile kitabi dindarlık alt boyutu arasında artı (+) yönde 0,922 puanlık bir ilişki olduğu görülmektedir

9. Dindarlık boyutu ile halk dindarlı̆ğ alt boyutu arasında artı $(+)$ yönde 0,848 puanlık bir ilişki olduğu görülmektedir

10. Dindarlık boyutu ile aktif yurttaşlık beceri alt boyutu arasında eksi (-) yönde 0,031 puanlık bir ilişki olduğu görülmektedir

11. Dindarlık boyutu ile aktif yurttaşılı katılımcı alt boyutu arasında eksi (-) yönde 0,289 puanlık bir ilişki olduğu görülmektedir

12. Dindarlık boyutu ile aktif yurttaşlık değer alt boyutu arasında eksi (-) yönde 0,203 puanlık bir ilişki olduğu görülmektedir

12. Dindarlık boyutu ile aktif yurttaşlık bilgi alt boyutu arasında eksi (-) yönde 0,079 puanlık bir ilişki olduğu görülmektedir.

Tablo 8 Dindarlık ile Aktif Yurttaşılı Arasındaki İlişki Derecesi ve Yönü (Regresyon)

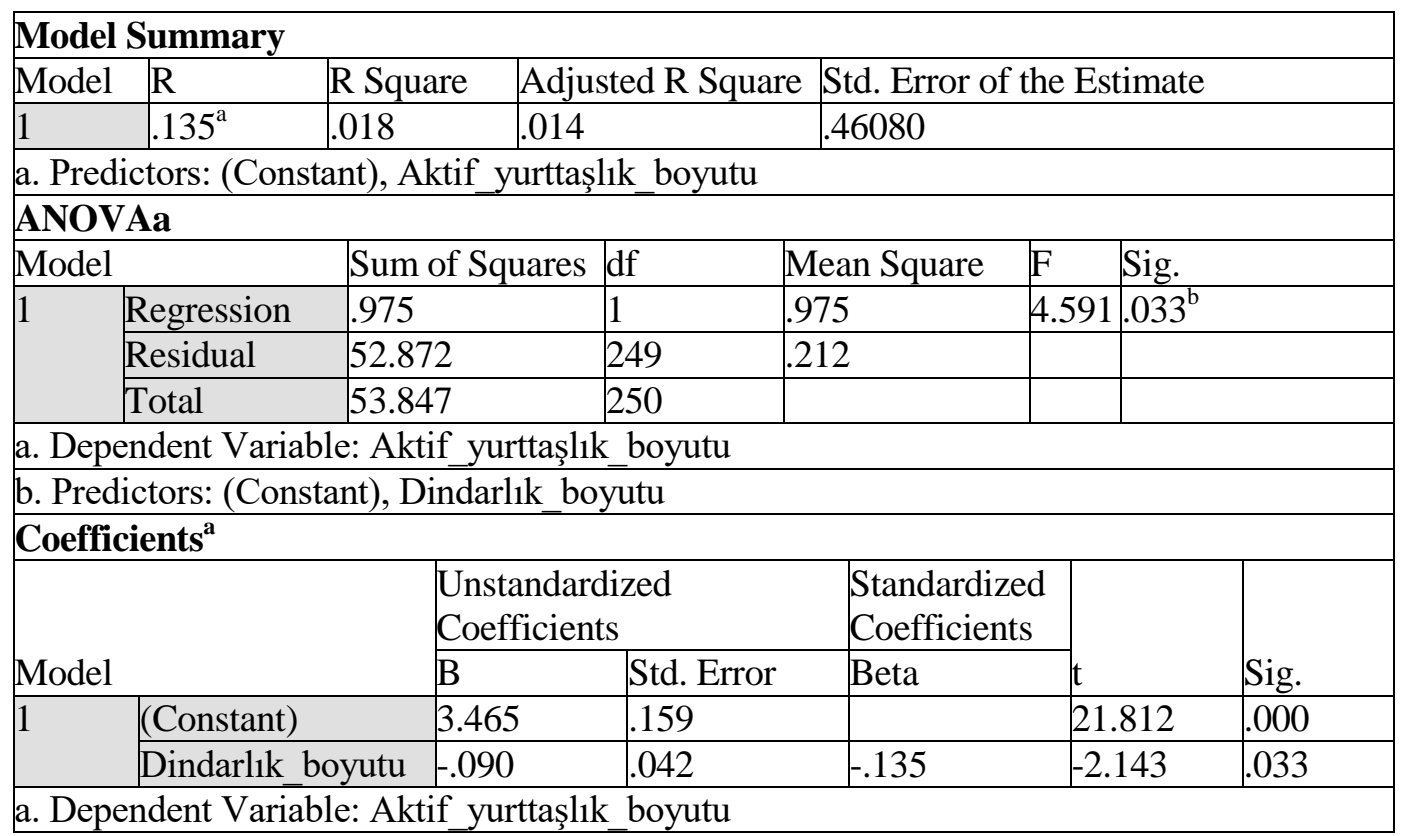

Araştırmanın bağımlı ve bağımsız değişkenleri birer tanedir. Bu nedenle bağımsız değişkenin bağımlı değişkene ait varyansın ne kadarını açıkladığını görmek için basit doğrusal regresyon analizi yapılmıştır.

Araştırmanın bağımsız değişkeni olan dindarlık durumu arasındaki ilişki durumunu gösteren $\mathrm{R}$ değeri $.135^{\prime}$ dir. Bu değer bağımlı değişken ile bağımsız değişken arasında önemsenecek doğrusal bir ilişki olduğunu göstermektedir.

Bağımlı değişkene ait varyansın \% kaçının bağımsız değişken tarafından açıklandığını gösteren $\mathrm{R}^{2}$ değeri .018'dir. $\mathrm{Bu}$ da bağımsız değişkenin bağımlı değişkenin varyansının 18'ini açıkladığını göstermektedir. Regresyon modeline müdahil başka değişkenler olduğunda $\mathrm{R}^{2}$ değerinde meydana gelen 
değişikliği gösteren (uyarlanmış $\mathrm{R}^{2}$ ) değeri. 014'dür. Aradaki farkın başka değişkenlerden kaynakladığını söylenebilir. Diğer bir ifadeyle tek başına aktif yurttaşlık durumunu tek başına dindarlık durumu ile açıklayamayız.

F değeri olan 4. 591'e denk gelen Sig değeri .033'tür. Bu değerin 0.005 'ten $(\mathrm{P}<0.05)$ küçük olmas1 dindarlık durumunun bağımlı değişken olan aktif yurttaşlığı açıklamada önemli katkısının olduğunu göstermektedir.

Tabloda B değeri -.090 ve B'ye ait standart hata değeri ise .042'dir. B değerine ilişkin standardize edilmiş regresyon katsayısı olan Beta -.135 , Beta değerine ait $t$ değeri -2.143 ve Sig .033'tür. Sabit değişkene denk gelen B değeri ise 3.465 olarak bulunmuştur. Buna göre katılımcıların dindarlık durumu ile aktif yurttaşlık durumları arasında basit regresyon modeli çerçevesinde istatistiksel olarak anlamlı negative ve orta derecede bir ilişki olduğu söylenebilir.

\section{SONUÇ}

Aktif yurttaşlık ile eğitim, ekonomik durum, cinsiyet, dindarlık durumu vb. olgusal durumlar arasında korelasyon olduğu yönde sosyal bilimciler arasında bir konsensüs bulunmaktadır. Ancak biz bu çalışmada bu olgusal durumlardan dindarlık durumu ile aktif yurttaşlık arasındaki ilişkiyi ortaya koymaya çalıştık.

Dindar, dine mensup olma, dini benimseme anlamındadır. Bu açıdan dinin gereğini kabul eden ve bir dine mensup olan herkes bu açıdan dindar sayılabilir. Ancak gündelik hayatta "dindar insan" dendiğinde genellikle sadece bu kadarı kastedilmez veya anlaşılmaz, göreceli olarak dine daha bağlı insan akla gelir. Bir insanın dindarlık durumu dendiğinde de o insanın mensubu olduğu dinin esaslarını içselleştirmesi ve ibadetlerini yerine getirmede gösterdiği bağll1ık derecesi anlaşılır.

"Yurttaşlık" kavramı hem etimolojik, hem de kavramsal olarak mekâna ve gruba göndermede bulunan bir sözcüktür. Günümüzde yurttaşlığın mekânsal boyutuyla genişlemesi ve katılımcılık boyutuyla farklılaşması yurttaşlık nitelikleri açısından beklentileri yükseltmiştir. Modern dünyada yurttaşlık ilişkilerindeki bu çeşitlenme "aktif yurttaşlık kavramını ortaya çıkarmıştır.

Dindarlık İle Aktif Yurttaşlık Arasındaki İlişkinin Sosyolojik Açıdan İncelenmesi hedeflediğimiz bu araştırmada katılımcıların, yukarıda tanımlandığı şekliyle dindarlık durumları ile yine yukarında tanımlandığı şekliyle aktif yurttaşlık durumları arasında bir ilişki olup olmadığının; ilişki varsa bu ilişkinin hangi düzeyde ve hangi yönde olduğunun belirlenmesi çabasıyla sınırlı tutulmuş ve "aktif yurttaşlık" (bilgi, beceri, değer ve katılım), ve dindarlık (kitabi dindarlık, halk dindarlı̆̆ı) boyutlarını ile bu boyutların alt boyutları belirlenmiş̧ir. Daha sonra elde edilen veriler kullanılarak araştırmanın hazırlık aşamasında belirlen boyutlar ve bu boyutların alt boyutları arasındaki korelasyon çeşitli yönleriyle ele alınmaya çalışılmıştır.

Araştırmanın bağımsız değişkeni olan dindarlık durmunun, bağımlı değişken olan aktif yurttaşlı durumuna ait varyansın ne kadarını açıkladığını görmek için basit doğrusal regresyon analizi yapılmıştır. Analiz sonucunda katılımcıların dindarlık durumu ile aktif yurttaşlık durumları arasında basit regresyon modeli çerçevesinde istatistiksel olarak anlamlı negative ve orta derecede bir ilişki olduğu görülmüş̧ür.

Araştırmada belirlenen ana boyutlar ile bu ana boyutların kendi alt boyutları arasında artı (+) yönde ve oldukça yüksek oranlarda korelasyon olduğu görülmektedir. Ancak araştırmada belirlenen iki ana boyut olan dindarlık durumu ile aktif yurttaşlık durumu arasına eksi (-) yönde düşük oranlı bir korelasyon olduğu görülmektedir. Bu sonuçlarda hareketle insanların dindarlık durumları arttıkça aktif yurttaşlık durumlarında az da olsa bir düşme olduğu söylemek mümkündür.

Bağımsız değişken olan dindarlık durumu ile bağımlı değişken olan aktif yurttaşlık durumuna ait varyansın ne kadarını açıkladığını görmek için basit doğrusal regresyon analizi yapılmıştır. Regresyon analizi sonucu bağımlı değişken ile bağımsız değişken arasında önemsenecek doğrusal bir ilişki olduğu ve bağımsız değişkenin bağımlı değiş̧kenin varyansının 18'ini açıkladığını göstermektedir. Regresyon modeline müdahil başka değişkenler olduğunda $\mathrm{R}^{2}$ değerinde meydana gelen değişikliği gösteren 
(uyarlanmış $\mathrm{R}^{2}$ ) değeri. 014'dür. Aradaki farkın başka değişkenlerden kaynakladığını söylenebilir. Diğer bir ifadeyle tek başına aktif yurttaşlık durumunu tek başına dindarlık durumu ile açıklayamayız.

Ayrıca Sig. değerinin 0.005 'ten $(\mathrm{P}<0.05)$ küçük olması dindarlık durumunun bağımlı değişken olan aktif yurttaşlı̆̆ı açıklamada önemli katkısının olduğunu göstermektedir. Buna göre katılımcıların dindarlık durumu ile aktif yurttaşlık durumları arasında basit regresyon modeli çerçevesinde istatistiksel olarak anlamlı negative ve orta derecede bir ilişki olduğu söylenebilir.

Sonuç olarak; yaptığımız bu çalışmanın en azından literatüre katkı sağlamasını ve yeni araştırmacılara bir basamak oluşturmasını umuyoruz. Aktif yurttaşlık ile dindarlık arasındaki ilişkinin yanında eğitim, aile ve siyaset gibi sosyal kurumlar ile aktif yurttaşlık arasındaki ilişkileri ve aktif yurttaşlığın önündeki engelleri konu edilen nitel ve nicel çalışmalar alandaki boşluğu doldurmada önemli katkılar sağlayacaktır.

Bilgilendirme / Acknowledgement: Bu makale Çankırı Karatekin Üniversitesi BAP biriminin desteğiyle yapılan bir araştırma projesinin verilerinden yaralanılarak hazırlanmıştır.

\section{KAYNAKÇA}

Arslan, H. ve Yazici, S. vd. (2016). Kırsal alanda aktif yurttaşlık: Sosyolojik bir alan araştırması. Çankırı: ÇAKÜ. Tamamlanmış BAP.

Arslan, H., Dil, K, Çetin, E. ve Yazıcı, S. (2017). Aktif yurttaşlık öz-yeterlik ölçeği: bir geçerlik ve güvenirlik çalışmas1. International Journal of Human Sciences, 14(3), 2797-2809.

Yazıcı, S., Arslan, H., Çetin, E. ve Dil, K. (2017). Aktif yurttaşlık ölçme aracının geliştirilmesi üzerine bir araştırma. Turkish Studies, 12(12), 251-272.

Arslan, M. (2003). Popüler dindarlık ölçeğinin geliştirilmesi: geçerlik ve güvenirlik çalışması. Din Bilimleri Akademik Araştırma Dergisi, 3(4), 97-116.

Arslantürk, Z. (2004). Dindarlı̆̆ı bă̆ımsız değişsenleri, dindarlık olgusu. İstanbul: Kurav Yayınları.

Çapçıŏlu, İ. (2013). Ana başlıklarıyla din sosyolojisi (ed. Niyazi Akyüz\& İhsan Çapçığlu). Ankara: Grafiker Yayınları.

Çetin, E., Yazicı, S., Arslan, H. ve Dil, K. (2017). Dindarlık ile aktif yurttaşlık arasındaki ilişkinin sosyolojik açıdan incelenmesi. Uluslararası Eğitim Yönetimi Formu(EYFOR8).

Geddes, M. J. (2000). Tackling social exclusion in the european union? The limits to the new orthotoxy of local partnership. International Journal of Urban and Regional Research, 24(4), 782-800.

Kurt, A. (2009). Dindarlığı etkileyen faktörler. Uludağ Üniversitesi Illâhiyat Fakültesi Dergisi, 18(2), 126.

Herbert- Cheshire, L. ve Higgins, V. (2004). From risky to responsible: expert knowledge and governing of community-led rural development, Journal of Rural Studies, 19, 283-302.

Hoskins, B., Jesinghaus, J., Mascherini, M., Munda, G., Nardo, M., Saisana, M., Nijlen, D. V., Vidoni, D. ve Villalba, E. (2006). Measuring Active Citizenship in Europe - EUR REPORT 22530. Joint Research Cetnr of the European Commission.

Morell, I. A. ve Bock, B. B. (2008). Dynamics of change and reconstitution in hegemonic and rural gender regimes. Gender Regimes, Citizen Participation and Rural Restructuring. (Eds. Morell, I. A. \& Bock, B.) Oxford: Elsevier. 
NCSS (2001). Creating effective citizens. NCSS position statement. 09.07.2019 tarihinde http://www. socialstudies.org/positions/effectivecitizens adresinden erişildi.

Neuman, W.L. (2007). Toplumsal araştırma yöntemleri: Nitel ve nicel yaklaşımlar (2. cilt). 2. bs. (çev. Sedef Özge). İstanbul: Yayınodas1.

Yıldız, M. (2001). Dindarlığın tanımı ve boyutları üzerine psikolojik bir çalışma. Tabula Rasa, 1(1), 1942. 